NBER WORKING PAPER SERIES

\title{
TAX SHELTERS OR EFFICIENT TAX PLANNING? A THEORY OF THE FIRM PERSPECTIVE ON THE ECONOMIC SUBSTANCE DOCTRINE
}

\author{
T. Christopher Borek \\ Angelo Frattarelli \\ Oliver Hart \\ Working Paper 19081 \\ http://www.nber.org/papers/w19081
}

\author{
NATIONAL BUREAU OF ECONOMIC RESEARCH \\ 1050 Massachusetts Avenue \\ Cambridge, MA 02138 \\ May 2013
}

Hart served as a testifying expert and Borek provided research support on behalf of the United States in WFC Holdings Corporation v. United States of America Civil Action No. 07-03320 (USDC D. Minn.) and Black \& Decker Corp. v. United States Civill Action No. 02-2070 (USDC D. Md.) Frattarelli was lead trial counsel for the United States in Black \& Decker. The views expressed are the authors', and do not represent the official position of the Tax Division, the Department of Justice, any other Government agency, or the National Bureau of Economic Research. We thank Karen Burke, Gabriel Cappelli and Andrei Shleifer for useful discussion, and helpful comments. Hart gratefully acknowledges financial support from the U.S. National Science Foundation through the National Bureau of Economic Research.

NBER working papers are circulated for discussion and comment purposes. They have not been peerreviewed or been subject to the review by the NBER Board of Directors that accompanies official NBER publications.

(C) 2013 by T. Christopher Borek, Angelo Frattarelli, and Oliver Hart. All rights reserved. Short sections of text, not to exceed two paragraphs, may be quoted without explicit permission provided that full credit, including $\odot$ notice, is given to the source. 
Tax Shelters or Efficient Tax Planning? A Theory of The Firm Perspective On the Economic Substance Doctrine

T. Christopher Borek, Angelo Frattarelli, and Oliver Hart

NBER Working Paper No. 19081

May 2013

JEL No. C24,D02,D23,G34,H25,K34

\section{ABSTRACT}

Courts have articulated a number of legal tests to distinguish corporate transactions that have a legitimate business or economic purpose from those carried out largely, if not solely, for favorable tax treatment. We outline an approach to analyzing the economic substance of corporate transactions based on the property rights theory of the firm, and describe its application in two recent tax cases.

T. Christopher Borek

Analysis Group

1899 Pennsylvania Avenue, Suite 200

Washington, D.C. 20006

cborek@analysisgroup.com

Angelo Frattarelli

Tax Division

U.S. Department of Justice

555 4th Street, N.W.

Washington DC 20001

angfrattarelli@yahoo.com
Oliver Hart

Department of Economics

Littauer Center 220

Harvard University

Cambridge, MA 02138

and NBER

ohart@harvard.edu 


\section{Introduction}

Policy makers have long faced challenges in designing and implementing tax legislation that provides the intended benefits while at the same time avoiding abuse. This tension is well illustrated in a long and diverse series of United States tax shelter cases in which parties disagree over the nature of tax-advantaged transactions: corporations, or taxpayers, argue that the terms of the transaction comply with the tax code while the government argues that the transaction violates the spirit of that law. In order to address challenges associated with interpreting complex provisions of the tax code, the Courts have established an economic substance test that is based on evaluating whether a taxpayer would have undertaken the actions at hand absent their tax consequences.

Traditionally some sort of discounted cash flow analysis is used to evaluate the economic substance of tax-motivated transactions. Such an analysis compares the incremental, riskadjusted benefits of the activities with the incremental risk-adjusted costs, ignoring taxes. The purpose is to determine whether the taxpayer could reasonably expect to realize a profit absent the disputed tax benefits. Discounted cash flow analyses are based on principles of corporate finance that are widely accepted in both business and academic settings. However, a serious shortcoming of such analyses is that they can be very sensitive to long-term financial projections and estimates of discount rates that are developed in the context of litigation, sometimes many years after the fact. ${ }^{1}$

The argument put forward here - consistent with those made in recent court cases - is that additional principles of economics and corporate finance, based on the modern theory of the firm, can be helpful in evaluating the economic substance of corporate reorganizations. In particular, according to the property rights theory of the firm, a key difference between an arm's length transaction and a transaction inside an organization concerns who has residual control rights, that is, who has the right to determine what happens in events not covered by explicit contractual terms. The possession of residual control rights can have important efficiency consequences in a world where contracts are incomplete. Among other things, to motivate individuals it may not be enough to offer them high-powered incentives; it may be necessary also to allocate them ownership or residual control rights.

In many transactions leading to the creation or reorganization of corporate entities no meaningful transfer of residual control rights actually occurs. These transactions are structured in such a way that both before and after the transaction the company initiating the transaction has complete control. This suggests that the same benefits could have been

\footnotetext{
1 Discounted cash flow models can also be manipulated (Damodaran 2007).
} 
achieved in-house: that is, such reorganizations or creations of a new entity lack economic substance and should not be respected for tax purposes.

The purpose of this paper is to spell out these arguments in more detail. We begin in Section 2 with a discussion of the economic substance doctrine. In Section 3 we review the property rights theory of the firm and explain how it applies to corporate reorganizations. In Section 4 we provide a brief overview of "contingent liability tax shelters" involving corporate transactions/reorganizations that, based on taxpayer claims, entitle the taxpayer to what amounts to a double deduction on certain anticipated expenses. In Sections 5 and 6 we apply the property rights theory of the firm to two unrelated contingent liability tax shelter cases that were litigated in federal court: The Black and Decker Corporation v. United States, and WFC Holdings Corporation v. United States. In Section 7 we discuss how the analysis from those cases can be extended to other sorts of corporate transactions and tax shelters. Conclusions follow in Section 8. In the appendix, we provide further background on contingent liability tax shelters

\section{Role of the Economic Substance Test In Corporate Taxation}

For nearly eight decades, federal courts have disregarded transactions (and the associated claims to tax benefits) that complied with literal terms of the tax code but served no purpose but to reduce taxes. The seminal case of Gregory v. Helvering (293 U.S. 465 [1935]) is often cited for the proposition that "the legal right of a taxpayer to decrease the amount of what otherwise would be his taxes, or altogether avoid them, by means which the law permits, cannot be doubted" (Gregory, 293 U.S. at 469). However, the taxpayer in Gregory lost because the Supreme Court found that

The whole undertaking, though conducted according to the terms of [the statute], was in fact an elaborate and devious form of conveyance masquerading as a corporate reorganization, and nothing else.... The transaction upon its face lies outside the plain intent of the statute. To hold otherwise would be to exalt artifice above reality and to deprive the statutory provision in question of all serious purpose.

(Gregory, 293 U.S. at 470).

Five years later, the Supreme Court explained that its holding in Gregory, which addressed the transfer of assets for no apparent business reason, supports "the natural conclusion that transactions, which do not vary control or change the flow of economic benefits, are to be dismissed from consideration." (Higgins v. Smith, 308 U.S. 473, 476 [1940]). Subsequent holdings have echoed this theme and form the foundation for the economic 
substance doctrine that courts have applied to disregard tax motivated transactions that violate the spirit and intent - if not the statutory text - of the Internal Revenue Code. ${ }^{2}$

But what does economic substance mean? A uniform definition has not fully emerged, and one commentator has described the economic substance test as akin to a "smell test." (Lederman 2010, 392) Unresolved questions include the following: Is it enough that the non-tax benefit is positive, or must the non-tax benefit be significant relative to the tax benefit? Should the non-tax benefit be assessed in primarily ex-ante or ex-post terms? For instance, does a transaction that ex-ante had a reasonable prospect of a gain (in terms of expected profits, say) but actually yielded a loss have economic substance? Conversely, does a transaction that ex-ante seemed unprofitable (in terms of expected profit) but expost yielded a gain have economic substance? Suppose that a transaction can be carried out in two different ways. Both yield positive non-tax benefits but the one with higher nontax benefits is less profitable overall given the tax consequences. Does the overall-lessprofitable option pass the economic substance test?

Standards regarding the economic substance test were particularly muddled in 2001 when the IRS announced that it would disallow losses generated by contingent liability tax shelters because "the overall transaction lacks sufficient economic substance to be respected for tax purposes” (IRS Notice 2001-17, 2001-1 C.B. 730). Although the IRS Notice relies on ACM Partnership v. Commissioner (157 F. 3d 231 [3 ${ }^{\text {rd }}$ Cir. 1998], cert denied, 526 U.S. 1071 [1999]), the Third Circuit's formulation of the economic substance test differed somewhat from the test applied in other circuits. For example, the Fourth Circuit in Rice's Toyota World, Inc. v. Commissioner (752 F. 2d 89 [4th Cir. 1985]) adopted a two-prong test that would disregard a transaction as a sham for tax purposes if it was (1) motivated by no business purpose other than obtaining tax benefits; and (2) the transaction has no economic substance because no reasonable expectation of profit exists (Rice's Toyota World, 752 F. 2d at 91-92). Conversely, the Eleventh Circuit found that a transaction that has "no economic effects other than the creation of tax benefits" lacks merit regardless of the taxpayer's subjective intent (Kirchman v. Commissioner, 862 F. 2d 1486, 1490 [11 ${ }^{\text {th }}$ Cir. 1989]). The court in ACM adopted a flexible approach, noting that business purpose and

2 See, for example, Knetsch v. United States (364 U.S. 361 [1960]) (denying interest deductions on offsetting loans and annuity contracts); Frank Lyon Co. v. United States (435 U.S. 561, 573, 98 S. Ct. 1291, 1298, 55 L. Ed. 2d 550 [1978]) (respecting a sale/ leaseback transaction compelled by regulatory realities that was not shaped solely by taxavoidance features). The economic substance doctrine is related to other judicial doctrines including the substance over form test, the step-transaction test (to collapse a series of interrelated or dependent transaction steps); and the sham transaction test (to challenge transactions that exist only on paper). All are based on the premise that "the simple expedient of drawing up papers" will not control the tax treatment of a transaction if the objective economic realities do not comport with the form in which the deal has been cast (Commissioner v. Tower, 327 U.S. 280, 291, 66 S. Ct. 532, 538, 90 L. Ed. 550 [1946]). 
objective profit potential "are not discrete prongs of a 'rigid two-step analysis,' but rather represent related factors both of which inform the analysis of whether the transaction had sufficient economic substance, apart from its tax consequences, to be respected for tax purposes" (ACM Partnership, 157 F. 3d at 247).

By 2006, as more and more tax shelter cases reached the federal courts of appeals, decisions issued by the various circuits (including the Fourth Circuit in the Black \& Decker case discussed in more detail below) coalesced around a common element that required taxpayers to show that their transactions, viewed objectively, offered some non-tax benefit: see Black \& Decker Corporation v. United States (436 F. 3d 431, 442-443 [4th Cir. 2006]) ("The ultimate determination of whether an activity is engaged in for profit is to be made by reference to objective standards."), quoting Hines v. United States (912 F. 2d 736, 740 [4 ${ }^{\text {th }}$ Cir. 1990]); Coltec Industries, Inc. v. United States (454 F. 3d 1340, 1356-57 [Fed. Cir. 2006]) ("While the taxpayer's subjective motivation may be pertinent to the existence of a tax avoidance purpose, all courts have looked at the objective reality of the transaction [in] assessing its economic substance."); Dow v. United States (435 F. 3d 594, 599 [6 ${ }^{\text {th }}$ Cir. 2006]); Klamath Strategic Investment Fund v. United States (568 F. 3d 537, 544 [5 $5^{\text {th }}$ Cir. 2009]) ("[I]f a transaction lacks economic substance compelled by business or regulatory realities, the transaction must be disregarded even if the taxpayers profess a genuine business purpose without tax-avoidance motivations"); Sala v. United States (613 F. 3d 1249, 1254 [10 $0^{\text {th }}$ Cir. 2010]).

In 2010, Congress codified an economic substance test and clarified certain questions that were not uniformly addressed by the judicial formulations (U.S. Department of Treasury 2010). The new legislation provides that in the case of any transaction to which the economic substance doctrine is relevant, the transaction shall be treated as having economic substance only if (i) the transaction changes in a meaningful way (apart from Federal income tax effects) the taxpayer's economic position, and (ii) the taxpayer has a substantial purpose (apart from Federal income tax effects) for entering into the transaction. 26 U.S.C. 7701(0)(1). Thus, the legislation mandates that the transaction must have both objective economic substance and a business purpose to be respected for tax purposes. On the objective element, the legislation provides that "a transaction's potential for profit shall be taken into account in determining whether the [economic substance] requirements ... are met only if the present value of the reasonably expected pre-tax profit is substantial in relation to the present value of the claimed net tax benefits." 26 U.S.C. $7701(0)(2)(A)$. That is, the legislation makes clear that non-tax economic benefits should be assessed in ex-ante terms and that they need to be significant relative to the tax benefits for the transaction to be tax-favored. We are not yet aware of any cases that have applied the 2010 codification of economic substance and business purpose to determine the propriety of tax benefits generated by aggressive transactions. 


\section{A Review of the Property Rights Theory of the Firm}

\subsection{The Basic Approach}

The question of why some transactions take place in firms and others take place through the market was first raised by Ronald Coase in his famous 1937 article (Coase 1937). Since that time progress on the question has been made by Williamson $(1975,1985)$ and Klein et al. (1978), among others. For our purposes a more recent strand of the literature called Property Rights Theory ("PRT") will be helpful and we begin by reviewing it here. ${ }^{3}$ PRT shares several features with Coase, Williamson, and Klein et al.'s Transaction Cost economics ("TCE"), but there are also some important differences.

PRT, in common with TCE, takes the view that firms arise when parties are engaged in long-term relationships and make relationship-specific investments. A useful example is an electricity plant that locates next to a coal mine (Joskow 1985). Ex-ante there may be many mines that the plant could locate next to, but ex-post, after its location decision, the plant has little flexibility about its source of coal.

In an ideal world, the parties would govern a relationship like this via a long-term contract. The contract would state what each party's obligations are in all contingencies during the course of the relationship. In practice, it is very difficult to write a comprehensive longterm contract for several reasons, one of which is the difficulty of predicting the future. Instead parties write contracts that are incomplete. Incomplete contracts specify some obligations of the parties and some contingencies but not others. They are vague and ambiguous in places. They tend to be short-term rather than long-term. They will be renegotiated as time passes and the parties respond to new events.

Lawyers and judges are, of course, extremely familiar with the concept of contractual incompleteness and the role of the courts in completing an incomplete contract. What has been less appreciated in the legal literature, and, until recently, in the economics literature, is that there is another important and very familiar mechanism for completing incomplete contracts. This mechanism involves asset ownership and firm boundaries and it lies at the heart of PRT.

\footnotetext{
${ }^{3}$ The PRT is discussed in detail in Grossman and Hart (1986), Hart and Moore (1990), Hart (1995), and Hart (1989). For recent extensions of Property Rights Theory, see Hart and Moore (2008), Hart (2008), Hart (2009), and Hart and Holmstrom (2010). For appraisals of Property Rights Theory, see Holmstrom and Roberts (1998), Whinston (2003), and Aghion and Holden (2011). For empirical work consistent with the theory, see Acemoglu et al. (2010), Baker and Hubbard (2003, 2004), and Kaplan and Stromberg (2003). For a survey of empirical work on transaction cost economics and property rights theory, see Lafontaine and Slade (2007).
} 
PRT takes the view that the owner of an asset or a set of assets, such as a firm, has the ability to fill in certain aspects of an incomplete contract. Specifically, the owner of an asset has residual rights of control; that is, the right to decide all uses of the asset not specified in an initial contract (as long as these uses are consistent with the law). In practice, owners often don't exercise residual control rights themselves-they delegate them to a board of directors. This is not important for the basic theory, however, and in what follows, we use owner and board interchangeably. We will, however, make a distinction between the case where the person managing an asset or set of assets owns or controls these assets himself and the case where he doesn't, that is, he runs a division or subdivision and is answerable to an owner or a board.

To see why the allocation of residual control rights matters, consider the electricity plant and the coal mine, and suppose initially that they are separately owned. Assume that the electricity company needs the coal it burns to be pure but that it is hard to specify in advance what pure coal is because there are many potential impurities. Imagine that ash content is the relevant impurity, and suppose that high ash-content coal is more expensive for the electricity company to burn but is cheaper for the coal mine to mine. Given that the contract does not specify purity in sufficient detail, the coal mine may be within its rights to supply cheap high ash-content coal (in effect, it exercises its residual control rights over the characteristics of the coal supplied). The coal mine may be willing to renegotiate the contract and supply low ash content coal but only if it receives a much higher price. As a result, even with a long-term contract, the electricity company is vulnerable and may lose money. Anticipating problems like this over the course of the relationship the electricity company may find it unprofitable to locate next to the coal mine. ${ }^{4}$

Now consider the case where the electricity company buys the coal mine before locating next to it. If the coal mine manager is thinking of mining high ash-content coal the electricity company can intervene directly to forbid this action. Since the electricity company manager owns or is in charge of the coal mine, it can direct from which part of the mine the coal is taken. Moreover, if for some reason the coal company manager refuses to follow the electricity company's instructions, the electricity company can fire him and replace him with a better-behaved manager-something that was not possible when they were separate companies.

\footnotetext{
${ }^{4}$ One way to solve this "hold-up” problem is for the parties specify in their initial contract that the electricity company must locate next to the coal mine in return for an upfront payment. This works if the location decision is perfectly contractible. However, even if this is the case, other similar investment decisions - such as whether the electricity company should install a boiler that burns this particular mine's coal efficiently_are likely not to be contractible. We discuss the location decision for simplicity.
} 
Possessing residual control rights over the coal mine thus makes the electricity company less vulnerable and encourages it to locate next to the coal mine. However, there is a downside. The electricity company's ability to intervene in the coal mine's operations makes the coal manager more vulnerable. Suppose that the coal manager has an idea about how to mine the coal more efficiently. When the coal mine was separate, this idea would lead to higher profits for the coal mine, and, if the manager owned the mine, these would end up in the coal manager's pocket. Now that the electricity company owns the coal mine, however, the electricity company may be able to implement the idea without rewarding the manager adequately. Suppose that the electricity company promises the coal manager a fraction of the cost savings he brings about. Costs are notoriously difficult to measure, and the electricity company may be able to use its residual control rights to manipulate these, for example, the electricity company could charge some of the electricity company's expenses to the coal mine. ${ }^{5}$ Another possibility is that the electricity company may decide not to implement the manager's idea at all ${ }^{6}$. It could be that the idea has a marginal effect on profit and its principal benefit is that, if successful, it would enhance the coal manager's reputation and career prospects, which is not something that the electricity company cares about. Anticipating that he will not be rewarded for his ideas, either in financial terms or because the ideas won't be implemented, the coal manager has less incentive to work hard to identify and implement cost savings when the coal mine belongs to the electricity company than when it is independent.

In summary, there is a tradeoff concerning ownership of the coal mine. If the electricity company owns the coal mine, then the electricity company will have strong incentives to invest in the relationship, namely, to locate its plant next to the coal mine, but the coal mine manager will have weak incentives to identify cost savings. On the other hand, if the coal mine is independently owned, then the electricity company will have weak incentives to invest in the relationship, but the coal mine manager will have strong incentives to identify cost savings. ${ }^{7}$ This trade-off is central to understanding how ownership structure can affect substantive economics outcomes, according to PRT.

It is worth reemphasizing the three key features of PRT: incomplete contracts, residual control rights, and assets. Contractual incompleteness is important because, in its absence, parties could regulate their relationship entirely via a long-term contract, so ownership

\footnotetext{
${ }^{5}$ For discussions of the ability of people to manipulate budgetary or accounting data in order to subvert incentive arrangements, see Lev (2003) and Jensen (2001). It is well known that cost manipulation and questionable accounting practices are hazards in, for example, the movie industry; see Bibicoff (1991) and Caves (2003).

${ }^{6}$ For a discussion of how the allocation of control or authority affects the incentive to have and implement ideas, see Aghion and Tirole (1997).

7 The version of PRT described above emphasizes non-contractible relationship-specific investments as the determinants of organizational form. A more recent part of PRT emphasizes other factors. See, for example, Hart (2009) and Hart and Holmstrom (2010).
} 
and firm boundaries wouldn't matter. Residual control rights are important because they tell us how incomplete contracts get completed via the allocation of ownership. Finally, assets-more precisely physical or nonhuman assets-are important because it is with respect to these that residual control rights are exercised. ${ }^{8}$

\subsection{Understanding Why Firms Reorganize}

The approach described above can throw light on why the boundary between firms and contracts (or markets) matters. The approach can also help us understand why firms restructure in response to changes in external events.

Various types of restructuring have become common over the last thirty years and have arguably produced large increases in value. These include leveraged buyouts ("LBOs"), management buyouts ("MBOs"), corporate spin-offs, and equity carve-outs. The success of these organizational forms can be understood using the theory of the firm and PRT can also explain why the creation of a new business enterprise or a new organizational structure is necessary for the generation of value in these cases.

In an LBO or MBO, a company or a company division is taken private either by management or another group. These transactions involve the heavy use of debt to purchase the ownership of the entity from its public shareholders or from its parent company. The transactions are characterized by increased management ownership, increased pay-forperformance, the addition of large, active investors to the board of directors, and the loss of access to public equity markets. The transactions are common in companies and industries that are growing slowly and are generating substantial amounts of cash, much of which is wasted on inefficient investments.

In a spin-off, a publicly traded company distributes some of its assets and liabilities to a newly formed company and the equity in that company is distributed to the shareholders of the parent company. Each corporation, including the original but now smaller parent, is a separate public company, and, in contrast to an LBO or MBO, most of the ownership rights remain with public shareholders.

Equity carve-outs are similar to spin-offs, except that, instead of distributing shares to the public, the parent sells a portion to the public and often retains a majority or controlling interest in the carved-out entity.

\footnotetext{
${ }^{8}$ There is no point owning a firm that consists entirely of human assets since (in the absence of slavery) an owner cannot directly force a worker to do something. In contrast, an owner can decide unilaterally how a physical asset is to be used.
} 
It is not hard to see why an LBO or MBO structure is conducive to efficiency gains. The combination of pay-for-performance, high debt, and significant managerial ownership means that good performance is highly rewarded while bad performance is heavily penalized. In other words, incentives are high-powered. This is very different from the situation that many managers face in large corporations, where the relationship between pay and performance is relatively weak.

An important question is, why is it not possible to duplicate the high-powered incentives of an LBO or MBO while staying within the confines of the original corporate entity, that is, without a corporate restructuring? We do, after all, see the use of incentive schemes in companies. Consider a company that is planning to sell a division to private investors via an LBO or MBO. Why can't the company generate the same efficiencies in the following manner: maintain the managers as employees and put them on an explicit incentive scheme, whereby they receive very large bonuses if divisional profit is high and low salary or even dismissal if divisional profit is low?

PRT explains why a restructuring is necessary to generate value. The LBO/MBO entity and the original company have a completely different control structure. A division inside a large company is not controlled by the people working in the division. Control is held by headquarters (the CEO or board of directors of the parent). This creates problems in sustaining high-powered pay-for-performance incentives, just as in the electricity-coal example discussed earlier. Suppose that headquarters tries to create strong incentives inside the large company by writing a contract promising the divisional manager a large bonus if his division does well. The problem is that divisional profits are not well-defined because costs are fungible. In particular, what is to stop headquarters from manipulating divisional profit after the fact, such as charging extraneous expenses to the division, thus making divisional profit look smaller than it really is? To the extent that the divisional manager anticipates this, the behavior by headquarters is self-defeating since it will reduce the divisional manager's incentives to generate high profit. However, self-defeating behavior may be hard to avoid: there may simply be no credible way for headquarters to commit ahead of time not to behave opportunistically.

All this changes after an LBO or MBO. Now those whose actions most affect the profitability of the enterprise -- top managers and a few key "outsiders" -- collectively own the (former) division, in the sense that they hold both the claims to divisional profits and the (residual) control rights. Nobody can intervene to manipulate the profits of the entity. Nobody can turn down their ideas. Nobody can tell them what to do or fire them. Their incentives to generate an efficient outcome are therefore quite different and far greater. 
Spin-offs and equity carve-outs are similar in a number of ways to LBOs or MBOs, but there are also important differences. The main difference is that control does not shift as clearly as in an LBO or MBO.

In a spin-off, most of the ownership rights remain with public shareholders. However, there are two important changes that occur when a company is spun off. First, a layer of supervision or authority is removed from above the top unit managers. Previously, the top managers had a boss, the CEO of the parent company. This boss could turn down some of their ideas and veto some of their decisions. Now the only group to which they are answerable (apart from public shareholders) is the board of the spun-off company, and top managers are likely to have had considerable influence over the choice of this board. To a large extent, the unit's managers are masters of their own fate.

Second, the profits of the spun-off company have "integrity" in a way that the profits of a division of the parent did not. Once a unit is independent, an external group cannot siphon profits out of this unit by forcing the unit to engage in disadvantageous side-deals or by assigning expenses to the unit. As a separate legal entity, the spun-off unit can veto such transactions. The integrity of profits has two benefits. First, profit-based performance schemes become possible and credible. Second, a public market in the spun-off company's shares can function, and this market will provide important information about the spun-off company's prospects. This in turn can allow for better incentive-based performance compensation for managers (in the form of, for example, equity-based compensation) ${ }^{9}$.

Equity carve-outs are similar to spin-offs, except that, instead of distributing shares to the public, the parent sells a portion to the public and often retains a majority or controlling interest in the carved-out entity. At first sight, it may seem that such a restructuring should have no effect on performance. After all, according to PRT, a restructuring matters only if control shifts, and here control remains with the parent. However, a subtle change does occur. Since the board of directors of the carved-out entity owes a fiduciary duty to all shareholders, the parent is limited in its ability to siphon profit out of the entity or to engage in disadvantageous side-deals so as to benefit the parent. If it did so, it would open itself up to breach-of-fiduciary-duty suits from minority shareholders. This gives the carved-out entity's profit some integrity and provides some role for performance-based compensation, such as stock options. Of course, the parent probably still has some ability to manipulate profit and has the ability to intervene in other ways, namely through its majority board representation. Given that the new entity has limited independence, we would expect an equity carve-out to have a less powerful impact on managerial incentives than a spin-off. And we would expect both to have a less powerful impact than an LBO or

\footnotetext{
${ }^{9}$ See, e.g., Holmstrom and Tirole (1993).
} 
MBO, given that insiders typically have a small ownership stake in a spin-off or equity carve-out but a large ownership stake in an LBO or MBO, that is, their incentives in the latter are much higher-powered.

We may summarize the discussion of this section as follows. Restructurings create value because things are possible in the restructured entity that were not possible before. Specifically, the management of the restructured entity becomes more independent, and the profits earned by the new entity have greater integrity - they are less fungible and more transparent. It may even be possible to create a market in the new entity's shares. As a result, management can be motivated in new ways. This effect is most powerful in the case of LBO's and MBO's, but the effect, although muted, is still present in the case of spinoffs and equity carve-outs.

\section{Contingent Liability Tax Shelters}

Contingent liability tax shelters are typically based on corporate transactions that shift the responsibility for managing future expenses (such as environmental cleanup costs, estimated medical costs of employees and retirees, or anticipated payouts from productliability or other unliquidated claims) to a separate subsidiary. Such transactions may be very attractive in tax terms to the extent that they allow the taxpayer to take what amounts to a double deduction for future expenses. As one promoter put it:

With proper planning and structuring of a series of transactions, a taxpayer may be able to significantly accelerate the deduction (in the form of a capital loss) of such contingent costs. Such planning involves the use of a risk management company or a health care management company and the sale of some of the stock of the company to a third party manager, consultant or investor. With this approach, the taxpayer may be able to deduct a capital loss equal to the amount of the contingency. In addition, the management company may later be entitled to a second deduction for the same amount over time as the expenditures are actually incurred. (Black \& Decker v. United States, Civil Action No. 02-2070 (USDC D. Md.), Docket No. 71, Exhibit 2, "Accelerating Contingent Liabilities Deductions.")

Although the genesis of contingent liability tax shelters can be traced to an IRS revenue ruling issued in 1995 (Revenue Ruling 95-74), the IRS has disputed the legitimacy of the tax benefits claimed by taxpayers that lacked a valid non-tax reason for engaging in a contingent liability transaction. In 2001 it issued Notice 2001-17 to alert such taxpayers of its position:

The Internal Revenue Service and the Treasury Department have become aware of certain types of transactions, described below, that are being marketed to taxpayers 
for the purpose of accelerating and, in some cases, duplicating tax deductions. This notice is intended to alert taxpayers and their representatives that the losses generated by such transactions are not properly allowable for federal income tax purposes.

$\cdots$

Taxpayers assert several business purposes for these transactions. However, the Service and the Treasury are not aware of any case in which a taxpayer has shown a legitimate non-tax business reason to carry out the combination of steps described above. Moreover, the Service and the Treasury believe that any business purposes taxpayers may assert for certain aspects of these transactions are far outweighed by the purpose to generate deductible losses for federal income tax purposes.

Despite the IRS's stance, several companies filed suit to challenge the disallowance of the tax benefits they claimed, asserting that they were entitled to the tax deductions because the transactions generating the beneficial tax treatments were motivated by legitimate non-tax business purposes. Two of those disputes are described in detail below. The Appendix includes a more detailed discussion of contingent liability tax shelters.

\section{The Black and Decker Corporation v. USA}

In 1998, Black and Decker stood to realize a substantial capital gain from the sale of several business divisions. ${ }^{10}$ Like many companies, it also faced growing and uncertain expenses associated with its (self-insured) provision of employee and retiree health benefits. As a result, Black and Decker entered into a transaction that shifted the management of its employee and retiree healthcare benefits plans to a subsidiary, Black and Decker HealthCare Management, Inc. ("BDHMI"). BDHMI was responsible for managing the health care benefits for Black and Decker employees and retirees over the period 1999-2007. As of the end of 1998, the risk-adjusted net present value of the associated health care liabilities Black \& Decker would incur from 1999 through 2007 was estimated to be approximately $\$ 500$ million.

Under BDHMI, the individuals managing the company's health care expenses remained largely the same; in particular, a key manager ("Key Manager") continued in place. However, a retired company executive ("Company Executive") with relationships and prior management experience throughout the company was added to the BDHMI board. The

\footnotetext{
10 Unless otherwise noted, the facts from this section are drawn from Black \& Decker v. United States, Civil Action No. 02-2070 (USDC D. Md.), Docket No.174, Revised Joint Pretrial Order.
} 
Company Executive would be compensated with preferred stock that was to be valued based on the difference between the current baseline projections and the actual healthcare expenses as they transpired. In addition BDHMI would receive advice from an outside benefits consultant ("Benefits Consultant") whose sister company ("Sister Corporation") would own some of the preferred shares. Finally, health care claims would be processed by an outside company ("Processor").

As the discussion above suggests, BDHMI was also designed to yield significant tax benefits. The primary benefit was a capital loss from the sale of BDHMI preferred stock to the Company Executive. The amount of that deduction was approximately equal to the present value of the contingent liabilities transferred to BDHMI and, in effect, represented an acceleration of the deductions Black \& Decker claimed as the liabilities were paid. The secondary benefit was BDHMI's ability to continue to deduct as business expenses the healthcare liabilities it assumed. Thus, Black and Decker asserted that it was entitled to what amounted to a double deduction associated with its future employee health care expenses The IRS disagreed and the dispute ended up in court where the determination ultimately rested on whether or not the BDHMI transaction had economic substance.

\subsection{Background and Key Elements of the BDHMI Transaction}

To analyze that question using PRT, it is first necessary to describe the key elements of the transaction. After various modifications, BDHMI ended up in late 1998 with the following ownership and governance structure:

- BDHMI had one class of common stock and four classes of preferred securities. Black and Decker, Inc. and Black and Decker Canada (collectively, "Black and Decker") owned all the common stock and the Class A and E preferred securities, had $75 \%$ of the votes, and could elect six out of eight directors to the board.

- A trust set up by the Company Executive, owned the Series C preferred securities, which promised a total dividend of $\$ 80,000$ a year, had $12.5 \%$ of the votes, and could elect one director to the board.

- The Sister Corporation owned the Series D preferred securities, which paid a total dividend of $\$ 64,000$ a year, had $12.5 \%$ of the votes, and could elect one director to the board.

The BDHMI transaction also established a board of directors consisting of six representatives of Black and Decker, the retired Company Executive, and a representative of the Sister Corporation. 
Management did not change under BDHMI. The Key Manager, who managed health care expenses in Black and Decker before the creation of BDHMI became chairman of BDHMI; he remained an employee of Black and Decker.

BDHMI had the following assets and liabilities:

- BDHMI's assets consisted of long-term promissory notes from Black and Decker, paying interest and principal at various dates over the period 1999-2008. These notes came about as the result of transactions in which Black and Decker transferred approximately $\$ 560$ million in cash to BDHMI and BDHMI then loaned this money back to Black and Decker. BDHMI assets also included the proceeds from the sale of various securities to investors.

- BDHMI's "liabilities" consisted of its responsibilities for the payment of health care expenses of Black and Decker workers and retirees over the period 1999-2007. Note, however, that if BDHMI became insolvent, Black and Decker would be obliged to put in enough money to meet these health care expenses.

The series $C$ and D preferred shares could be called by BDHMI beginning on January 1 , 2004 , and could be put to BDHMI by their holders beginning on January 1,2006 . When these securities were called, put, or retired (on December 31, 2007), their holders would receive a liquidation or redemption value given by the following formulas:

- Series $\mathrm{C}$ total share value $=\min \{\$ 5$ million, $\$ 1$ million $+10 \% \Delta$ Equity Value $\}$,

- Series $\mathrm{D}$ total share value $=\min \{\$ 3.2$ million, $\$ 0.8$ million $+8 \% \Delta$ Equity Value $\}$

Here, $\Delta$ Equity Value represents the excess, if any, of the corporation equity value at the time of redemption over the initial value that was described in contracts governing the BDHMI transaction. In effect, the formula was such that the holders of the Series C and Series D preferred shares, the Company Executive and Sister Corporation, respectively, would receive some share of the measured cost savings of providing health benefits, with the Company Executive receiving 10\% of such savings and the Sister Corporation receiving $8 \%$ of such savings, up to a cap in each case. The formula for $\Delta$ Equity Value also included some positive and negative adjustments, which were purportedly designed to insulate the Company Executive and Sister Corporation from changes in costs beyond their control.

BDHMI had a three-year renewable consulting arrangement with the Benefits Consultant, whereby the Benefits Consultant agreed to provide administrative services on a fee-forservice basis. Black and Decker also had a contract with the Processor, whereby the Processor agreed to process health care claims. 


\subsection{Analyzing the Transaction}

What does the theory of the firm tell us about the economic substance of the Black and Decker-BDHMI transaction? Before 1999, Black and Decker employed personnel in the human resources department--in combination with outside consultants such as the Benefits Consultant and independent contractors such as the Processor. After the Black and Decker-BDHMI transaction, health care benefits were administered by a new entity, BDHMI, again in combination with the Benefits Consultant and the Processor. The Key Manager remained the same. The Company Executive was brought in as a board member and was compensated on the basis of the difference between actual healthcare expenses as they transpired and the contemporaneous baseline projections.

Can one argue that these organizational shifts brought efficiency gains that could not be achieved internally?

It is certainly true that some things changed. During the period December 1998 through September 2003, BDHMI suggested, and Black and Decker thereafter implemented, a number of proposals for reducing employee and retiree healthcare plan costs, including the following:

- encouraging retired employees to convert to health maintenance organizations as their healthcare providers;

- outsourcing the administration of the retiree health plan;

- increasing the portion of healthcare premiums paid by current and retired employees;

- increasing active and retired employees' co-payments for healthcare expenses;

- increasing active and retired employees' co-payments on prescription drugs;

- replacing the point of service and indemnity plans with a preferred provider organization ("PPO") plan;

- adopting a three-tier prescription drug co-pay system;

- creating a dental PPO for employees;

- adopting a two-tier benefit plan; and

- instituting a wellness lifestyle program, under which Plaintiff encouraged smoking cessation, weight loss, and exercise by banning smoking in all of its companies' facilities and vehicles, reimbursing employees for the prescription drug Zyban, offering on-site smoking cessation classes, reimbursing employees for Weight Watchers meeting costs, and subsidizing fitness programs.

The central question with regard to Black and Decker's tax claim is could these proposals have been implemented just as well without the creation of BDHMI? 
One approach to answering this question is to ask whether similar changes occurred at other companies that tried to control their health-care expenses, but did so in-house. However, even if there are examples like this, the argument can always be made that these other firms were different, and Black and Decker required another approach. Thus it is also useful to provide a more comprehensive answer. This is where PRT comes in. According to PRT, there is no substantive difference between a transaction inside a firm and between firms unless there is a shift in residual control rights. Thus the answer to the question--did forming BDHMI create value? -- hinges on whether residual control rights shifted to BDHMI.

A striking feature of the Black and Decker-BDHMI transaction is that residual control rights did not shift: Black and Decker maintained complete control over the operations of BDHMI. Specifically,

(a) Black and Decker had the majority of the votes of BDHMI;

(b) Black and Decker could elect the majority of the board members (6 out of 8) and could replace them at any time;

(c) all decisions of the BDHMI board had to be ratified by the Black and Decker senior vice president of human resources.

An implication of this is that the parties working on the provision of health care benefits for Black and Decker employees and retirees have no more independence after the transaction than they had before. Suppose that the Key Manager or the Benefits Consultant comes up with an idea for reducing costs. When health care benefits were administered and paid for inside Black and Decker, this idea would have had to be approved by the senior vice president and ultimately by the Black and Decker board. Now that BDHMI is a separate entity, this is still the case. First, as we have seen all decisions of the BDHMI board have to be ratified by the senior vice president. Second, given that Black and Decker appoints the majority of the BDHMI board and can replace its representatives at any time, it can easily veto any decision that it doesn't like.

To take another example, suppose that the Key Manager's performance starts to deteriorate and Black and Decker wants to replace him as a top manager. This was easy to do when health care benefits were managed in-house. However, it is still easy to do when BDHMI is a separate entity. Black and Decker can simply instruct the board to fire him or replace the majority of board members if it refuses to do this.

We noted in Section 3 that there are some restructurings, such as equity carve-outs, in which control does not shift and yet where there can be real effects on performance. These effects occur because the profits of the new entity have greater transparency and integrity 
and this can permit the use of performance-based compensation. Moreover, the benefits of performance-based compensation are increased if greater transparency of profits permits the creation of a public market in the carved-out entity's shares and the market yields important information about the entity's prospects.

It is hard to believe that the greater transparency of profits could have been an important factor in the present context. The key parties able to generate cost savings were the Key Manager, Company Executive, Benefits Consultant (and possibly the Sister Corporation). The Key Manager did not have a formal incentive scheme with BDHMI. The Benefits Consultant was paid on a fee-for-service basis. The Company Executive and the Sister Corporation held securities whose return was determined by a formula in which BDHMI profit did not appear directly. Furthermore, the parties specified a mechanism for determining the values of the variables that were in the formula--benefit liabilities plus various positive and negative adjustments: the ability to manipulate this variables was independent of ownership or control rights. Finally, BDHMI does not benefit from participating in public equity markets.

We do not intend to suggest that ownership and control could not be relevant in the Black and Decker-BDHMI transaction. For example, Black and Decker, through its majority board representation, can decide whether to fire the Key Manager or whether to renew the Benefit Consultant's contract. If control had shifted to the Key Manager or the Benefits Consultant (or the associated Sister Corporation), such decisions might conceivably have been made differently. This in turn might have affected the Key Manager's or Benefit Consultant's incentives. However, control did not shift--it stayed with Black and Decker.

For the above reasons, the United States was not swayed by Black and Decker's claim that the BDHMI transaction made management more independent and allowed the use of higher-powered incentive schemes, yielding efficiency gains. It is quite possible that health care benefits were not being managed efficiently inside Black and Decker before 1999 and that some improvements were feasible. In particular, there may have been an excessive focus on reducing short-term costs at the expense of generating long-term cost savings. However, given that there was no change in control, these improvements could have been achieved simply by changing the incentive arrangements between Black and Decker and its employees and outside contractors, rather than through the creation of a new business entity. Moreover, doing things this way would have saved substantial transaction costs associated with making BDHMI responsible for Black and Decker's health care liabilities; these costs ultimately amounted to nearly $\$ 3$ million in legal and other fees. 


\subsection{Disposition of the Case}

What did the court decide in The Black and Decker Corporation v. USA? Prior to trial the district court granted summary judgment in favor of Black and Decker under the sham transaction test. The judge's reasoning was that significant business activity took place within BDHMI, and so, even if the transaction was tax-motivated (which Black \& Decker conceded for summary judgment purposes), it was not a sham. The Fourth Circuit reversed the judgment for Black \& Decker and remanded the case to district court for trial. In doing so, the Fourth Circuit ruled that substantial business activity within BDHMI did not imbue the BDHMI transaction with economic substance. Rather, the BDHMI transaction had to have the potential to realize significant non-tax benefits in order for Black \& Decker to claim the tax benefits the transaction was designed to maximize. On that score the government offered ample evidence [from four expert witnesses] to permit a reasonable trier of fact to conclude that Black \& Decker lacked a reasonable expectation of earning a non-tax profit from the BDHMI transaction (The Black and Decker Corporation, 436 F. $3 \mathrm{~d}$ at 17). The case settled soon after, rendering the trial unnecessary.

\section{WFC Holdings Corporation v. USA}

Wells Fargo, a global financial services company, is another US taxpayer that engaged in a contingent liability transaction in 1998. The contingent liabilities Wells Fargo transferred related to real-estate leases estimated to be underwater by approximately $\$ 426$ million. ${ }^{11}$ As with Black and Decker, Wells Fargo asserted that it was entitled to what amounted to a double tax deduction: one in the form of a capital loss from the sale of stock it received in the initial exchange, and another in the form of ordinary and necessary business expenses associated with the transferred leases. The government, in contrast, asserted that the transaction that produced the capital loss was an economic sham and should be disregarded as such. We will see that the structure of the transaction is quite similar to that in Black and Decker, but that the transaction raises additional issues that PRT can help to resolve.

\subsection{Background and Key Elements of the Transaction}

As of 1998, Wells Fargo, as a result of mergers and office space consolidation, had sublet numerous properties to third parties. Many of these leases were underwater in the sense

\footnotetext{
${ }^{11}$ Unless otherwise noted, the facts described in this section are drawn from the district court's findings of fact in WFC Holdings Corporation v. United States of America (108 A.F.T.R. 2d 6531 [D. Minn. 2011]) and from the Report of Oliver D. Hart, submitted in WFC Holdings Corporation on December 1, 2008, which can be retrieved through PACER at https://ecf.mnd.uscourts.gov/doc1/10112809711.
} 
that Wells Fargo earned less from is subtenants than it was paying under the original leases.

In December 1998, Wells Fargo transferred securities and approximately two dozen underwater leases to Charter, a dormant subsidiary, under an exchange agreement. The difference between the present value of lease expenses and the present value of sublease income on the underwater leases was estimated to be approximately $\$ 425$ million. The transferred securities were intended to fund the lease liabilities and were nearly equivalent in value (after accounting for [nominal stockholder equity payments]). Together, the exchanged lease liabilities and securities accounted for virtually all the assets and liabilities of Charter.

As a result of the exchange, Wells Fargo received 100 percent of Charter's common stock and preferred shares. The preferred stock carried a 6.625 percent dividend and was voting, cumulative, and non-participating. In addition, if the tax laws on dividends changed, the dividend on the preferred shares would be adjusted so that preferred shareholders received the same amount in net terms as before the tax change. Further, a support agreement between Wells Fargo and Charter essentially guaranteed that Wells Fargo would make up any shortfall if Charter had insufficient funds to make the required dividend payments.

In February 1999 Wells Fargo sold 20 percent of the preferred shares to Lehman Brothers for $\$ 3,750,022.22 .15$. Thus, at this date, Wells Fargo owned all the common equity and 80 percent of the preferred equity in Charter, and Lehman owned 20 percent of the preferred equity. Each common and preferred share of Charter had one vote. Since Wells Fargo owned 630,000 shares of common stock and 16,000 shares of preferred stock, while Lehman owned 4,000 shares of preferred stock, Wells Fargo had over 99 percent of the votes. Although Wells Fargo required approval from Lehman to take certain actions affecting the rights of preferred shareholders, in all other matters, such as the selection of the board of directors, Wells Fargo had complete control.

As of December 1998, Charter's board of directors had three members. In addition, Charter had two officers. All of these individuals, except for possibly one, were also employees of Wells Fargo. The two senior managers had a formal bonus plan with Charter that involved a formulaic assessment of Charter's performance. These assessments were done annually and on a property-by-property basis. For each property, a benchmark calculation of the Net Present Value (NPV) of the underwater lease liabilities was made based on a December 1998 projection. These benchmark calculations were intended to capture the difference between what Charter was paying on the master leases and what it was receiving from subtenants. Charter's annual performance was measured by comparing revised NPV 
calculations that incorporated actual performance to date, as defined in the Executive Officer Bonus Plan, with the 1998 benchmark calculations.

Charter's aggregate performance was calculated as the sum of the gains associated with individual properties in which gains were achieved. That is, properties with measured losses were not included in each year's aggregate performance measurement. According to the bonus plan, as of 2003, the two senior managers were entitled to 6 percent and 4 percent, respectively, of the measured performance gains, as long as certain pre-specified thresholds were met. Based on \$56.8 million in calculated performance gains through 2003 , the two senior managers were entitled to $\$ 3.4$ million and $\$ 2.3$ million, respectively.

\subsection{Analyzing the Transaction}

What does the theory of the firm tell us about the economic substance underlying the Wells Fargo-Charter transaction? Before December 1998, Wells Fargo employed personnel in their Corporate Properties Group to manage their leases. After December 1998, 21 of these leases were transferred to Charter. The personnel working on the 21 leases remained essentially the same. Also, Charter's two senior managers had been and continued to be Wells Fargo employees.

The Business Case prepared by Wells Fargo highlighted two important economic benefits of creating Charter. First, managers would be incentivized to beat the market, and such incentives would likely contribute to the success of the project. Second, transferring the underwater leases to Charter would allow for improved negotiations with (prospective) subtenants that had deposit or borrowing relationships with Wells Fargo and had leveraged (or might leverage) these arrangements to get more favorable leasing terms.

There is a problem with both of these arguments. A striking feature of the Wells FargoCharter transaction is that Wells Fargo maintained complete control over the operations of Charter. Specifically, Wells Fargo had over 99 percent of the votes of Charter and could elect or replace the board of directors at any time. Further, the Support Agreement between Wells Fargo and Charter required Wells Fargo to maintain enough votes to be able to elect a majority of Charter's board of directors, so Wells Fargo would always remain in control of Charter. An implication of this was that the parties working on the management of leases had no more independence after the transaction than they had before. Suppose that one of the senior managers comes up with an idea for filling vacant properties, for example, a new marketing plan. When leases were managed by Wells Fargo's Corporate Properties Group this idea could be vetoed by Wells Fargo top management if it did not fit in with their overall strategy or they thought it was a mistake. 
This is still the case when the leases are managed by Charter. Given that Wells Fargo appoints the Charter board, it can veto any decision that it does not like. While Charter may be a separate legal entity, the senior managers and other Charter employees are no more autonomous from Wells Fargo than they were before.

To take another example, suppose that the performance of one of the senior managers starts to deteriorate and Wells Fargo wants to replace him. This was easy to do when leases were managed in-house. However, it is still easy to do when Charter is a separate entity. Wells Fargo can simply instruct the board to fire the senior manager and replace the board if it refuses.

Let us turn to the argument that negotiations with (prospective) subtenants that had deposit or borrowing relationships with Wells Fargo would change with the emergence of Charter. One rationale appears to have been that Wells Fargo bank customers would recognize Charter as distinct from Wells Fargo and no longer attempt to leverage their deposit or borrowing relationship to receive favorable sublease terms. It is hard to make sense of this given that Charter was not an independent entity; Wells Fargo had complete control over its board. Further, the people involved in managing the Charter leases were Wells Fargo personnel. Thus, any client who understood Charter's corporate structure would realize that its ability to persuade Wells Fargo to put pressure on the lease negotiators was exactly the same after the formation of Charter as before. Further, Wells Fargo continued to present its face to the subtenants of some underwater leases. As of June 30,1999 , no notices of transfer had been sent to the subtenants of 21 underwater leases and rent checks from subtenants continued to be paid to Wells Fargo. Finally, some of the materials associated with the sublease agreements indicated Wells Fargo involvement.

A second rationale, provided by Charter's two senior managers, is that the presence of the third party Lehman changed Charter's negotiating stance. The idea is that Charter could and did argue that it was unable to provide special deals for prospective subtenants with Wells Fargo banking relationships, given its obligations and fiduciary duty to Lehman. This claim could make sense if Lehman's returns from its investment in Charter actually depended in a meaningful way on the terms of the leases that Charter signed. However, this was not the case. The returns associated with Lehman's investment in Charter were prespecified and backed both by Charter and by Wells Fargo, through the Support Agreement mentioned above. Moreover, Charter's actions as they relate to potential good customer discounts had no practical effect on the combined financial integrity of Charter and Wells Fargo.

Of course, it may have been the case that prospective subtenants believed that Charter was independent even if it was not, or believed that Lehman's investment was at risk even if it 
was not. In other words it is possible that clients had wrong perceptions. However, the business purpose of a transaction that relies on subterfuge seems questionable ${ }^{12}$.

A further argument that one of the senior managers and others made is that to improve performance it was important for the leases to be separated from the day-to-day operations of the bank. However, creating a unit inside Wells Fargo whose sole purpose was to manage the leases would have achieved the same goal.

We noted in Section 3 that there are some restructurings, for example, equity carve-outs, in which control does not shift and yet there can be real effects on performance. These effects occur because the profits of the new entity have greater transparency and integrity, and this can permit the use of performance-based compensation. Moreover, the benefits of performance-based compensation are increased if greater transparency of profits permits the creation of a public market in the carved-out entity's shares, and the market yields important information about the entity's prospects.

It is hard to believe that the greater transparency of profits could be an important factor in Wells Fargo's case. The compensation of the key parties who may be able to improve the leasing was determined by a formulaic calculation that did not depend on Charter's ultimate profitability. Furthermore, Charter did not benefit from participating in public equity markets.

We may summarize the U.S. government's position as follows. The idea that the Wells Fargo-Charter transaction made management more independent and that this permitted the use of higher-powered incentive schemes, or allowed management to bargain more aggressively with lessees or lessors, is unconvincing. There was no change in independence. It is quite possible that leases were not being efficiently managed inside Wells Fargo before December 1998 and that some improvements were feasible. However, these improvements could have been achieved by changing the incentive arrangements between Wells Fargo and its employees via contract, rather than through the creation of a new business entity, Charter. Moreover, doing things this way would likely have saved significant transaction costs, just as in the Black and Decker transaction. ${ }^{13}$

\footnotetext{
12 Implicit in both these rationales is the idea that it is in Wells Fargo's interest that Charter be seen by subtenants as independent, so that they cannot leverage their deposit or borrowing relationships to get more favorable leasing terms. This is in fact far from obvious. Leverage might allow Wells Fargo to price discriminate, offering better deals to some subtenants (those with deposit or borrowing relationships) than to others (those without). We will not pursue this issue further, but simply note that it casts further doubt on the merits of the business case.

13 There is one important further consideration in the Wells Fargo case. Wells Fargo also had a regulatory motive for setting up Charter. Doing so allowed Wells Fargo to switch regulators from the Office of the Comptroller of the Currency to the Federal Reserve Board, which gave it a longer period of time to dispose of
} 


\subsection{Disposition of the Case}

Following a trial in October 2010, the district court found that Wells Fargo lacked a legitimate business purpose for engaging in its contingent liability transaction, and that the transaction lacked economic substance (which the court considered independently). Specifically, the Court found that:

- "Charter... is a straw entity controlled by WFC and created for the purpose of effectuating the [transaction]. Its nature undermines a finding of a 'genuine multiple-party transaction ...."'

- "Bringing in Lehman seemed to have no economic value of any kind" and the 1998 transaction was "simply not [that] of a company that sought to use the presence of an outside investor to deleverage good bank customers."

- "... any argument for efficiency based on the executive bonus plan is illusory", as Wells Fargo could have implemented such a bonus plan, with lower administrative costs, without the 1998 transaction. (WFC Holdings Corporation, 108 A.F.T.R. 2d at $70,85,99)$.

Each finding is based upon, and consistent with, the PRT principles that were presented to the court. Wells Fargo has appealed the ruling.

\section{Ownership, Control and Related Tax Disputes}

The economic substance of ownership is central in many tax disputes and the PRT framework proves useful in providing guidance beyond the two cases described above. Consider, for example, TIFD III-E vs. United States, commonly known as Castle Harbour. ${ }^{14}$ In this case the taxpayer argued that it had entered into a partnership with two Dutch banks, and that the banks had received an equity stake in the partnership. The taxpayer's argument that the transaction had the bone fide economic substance of raising equity capital rested critically on its assertions that the securities received by the Dutch banks

real estate that was owned but not used for banking purposes (namely, Other Real Estate Owned, or "OREO"). Without going into the question of whether regulatory shopping qualifies as a legitimate business purpose, let us just note that the regulatory benefits could have been achieved without bringing a third party, Lehman, into the transaction. This would surely have saved some legal and other costs. At the same time without a third party Wells Fargo would not have qualified for the tax benefits that the court found were at the heart of this transaction.

${ }^{14}$ Unless otherwise noted, the facts from this section are drawn from TIFD III-E Inc., the Tax Matters Partner of Castle Harbour-I Limited-Liability Company (342 F. Supp. 2d 94 [D. Conn. 2004], rev'd and remanded , 459 F. 3d 220 [2d Cir. 2006], judgment on remand 660 F. Supp. 2d 367 [D. Conn. 2009], rev’d 666 F. 3d 836 [2d Cir. 2012]. 
were properly characterized as equity. Both a trial court and an appellate court evaluated the nature of the cash flows associated with the securities, as well as the corresponding risks. Consistent with PRT, both courts examined whether the banks had received management or control rights. The trial court, however, sided with the plaintiff and held that even though the Dutch banks had not received any control or management rights, they had nonetheless received equity. The district court reasoned that the "average stockholder of a publically traded corporation has no management rights, but there is little doubt he holds equity" (TIFD III-E Inc., 342 F. Supp. $2 \mathrm{~d}$ at 39). Given that the lack of control rights did not automatically disqualify a security from being equity, the district court found that the securities received by the Dutch banks carried enough uncertainty and equity-like properties to be considered equity.

This superficial observation ignores the role that even those with individually small holdings of shares and votes can have in influencing and constraining managerial decisionmaking. Critically, small shareholders can form voting blocs and coalitions with other similarly situated shareholders, or can sell their shares and votes to an activist investor or takeover bidder who will then have enough votes to affect what the company does. This threat constrains the actions of a company's managers. ${ }^{15}$ Further, in the context of public companies, enough dissenting votes can signal significant dissatisfaction, leading managers to re-evaluate their strategy. Composition of ownership is critical here: small shareholders have power precisely because there is no large shareholder who can out-vote them.

In Castle Harbor, in contrast, the presence of a majority shareholder precluded the minority shareholder from any direct influence on decision-making. Even though the Dutch banks contributed nearly 20 percent of the partnership's assets, they were not entitled to any votes, and exercised no managerial control or influence. The district court found that FAA rules actively precluded the possibility of giving the Dutch banks a right to elect managers (TIFD III-E Inc., 342 F. Supp. $2 \mathrm{~d}$ at 18). Even without that limitation, the Dutch Banks securities' were, effectively, meaningless in controlling how the company would be run, and, as a result, lacked, as PRT highlights, the defining feature of ownership when viewed in terms of economic substance.

Ultimately, the Second Circuit (twice) overturned the district court and found that the "interest of the banks was not a bona fide equity participation," relying on an analysis of seven factors which it decided suggested that the banks had received debt, not equity. While the Second Circuit generally relied upon the district court's analysis of the cash flows associated with the Dutch banks' securities, it concluded that the risks associated with

\footnotetext{
15 There is a voluminous literature on activist investors and the market for corporate control. For a summary, see Shleifer and Vishny (1997).
} 
these securities were not sufficient to warrant their categorization as equity. In short, the Second Circuit determined that while the consideration received by the Dutch Banks had some of the superficial appearances of equity, the bulk of the evidence suggested that "the funds were advanced with reasonable expectations of repayment regardless of the success of the venture."

The conflicting decisions reached by the courts in Castle Harbor demonstrate the murky nature of characterizing debt and equity based on cash flows and risks. A wide variety of factors drive the underlying risks of the cash flow rights associated with a given security, and the corresponding risk profiles are challenging to measure. Further, there are many ways to formulate payment terms that are neither uniform and fixed (like those traditionally associated with debt) nor entirely "residual" (like those associated with equity). Establishing a "bright line" distinction between debt and equity in terms of income rights can pose significant challenges and may be open to abuse. ${ }^{16}$ PRT highlights that courts need not undertake such a difficult endeavor because, from an economic substance perspective, control is the defining characteristic of ownership and control rights are often much easier to identify. ${ }^{17}$.

Analysis of another case, Canal Corp. v. Commissioner, highlights a similar observation. ${ }^{18}$ In this case, the "taxpayer" formed what it characterized as a partnership with another large paper company, Georgia Pacific (GP), in which both contributed their respective tissue paper businesses. The partnership then borrowed money from an outside bank, which was guaranteed by GP. While GP received 95 percent of the partnership's equity, the taxpayer received a cash payout from the proceeds of the bank loan for nearly the entire value of the business it contributed.

The regulations under the Internal Revenue Code permit the IRS to re-characterize the contribution of a business to a partnership for cash as a disguised sale that (assuming the cash received exceeds the basis of the property contributed) triggers a taxable gain. After the IRS re-characterized the above-transactions as a sale, the taxpayer argued that the transaction was actually a debt-financed transfer of consideration that should qualify as an exception to the disguised-sale rule (Silverman and Nocjar 2011). This exception exists when a taxpayer transfers a business to a partnership, receives cash, but remains economically liable for some amount of the debt raised by the partnership. In such a case,

\footnotetext{
${ }^{16}$ For instance, see Englebrecht et al. (2008) and Financial Accounting Standards Board (2010), noting that one objective was to "Eliminate more than 60 pieces of current U.S. accounting literature that are inconsistent, subject to structuring, or difficult to understand and apply.”

${ }^{17}$ Of course, in practice income rights and control rights will often be held together and indeed there are strong economic reasons for this. See, for example, Grossman and Hart (1988) and Harris and Raviv (1988).

${ }^{18}$ Unless otherwise noted, the facts presented in this section are from Canal Corporation and Subsidiaries, Formerly Chesapeake Corporation and Subsidiaries v. Commissioner of Internal Revenue (135 T.C. 199 [2010]).
} 
the amount of the taxpayer's remaining liability can reduce the amount of the taxable gain. In Canal Corp, the taxpayer, through a subsidiary, indemnified the other partner's guarantee of the partnership's debt, and argued that this indemnity generated an economic interest in the liabilities of the partnership, greatly reducing its tax burden.

Of note, however, is the fact that the taxpayer had given up all management and control rights to its tissue paper business, and does not appear to have been able to influence or constrain managerial decision-making through covenants or other mechanisms in the indemnity. Rather, GP took over full control of the operation, apparently leaving the taxpayer with no recourse should GP take some action increasing the risk that the indemnity would be called. This did not expose the taxpayer to any real economic liability under the indemnity, however, because the indemnity (which GP did not request or require) only covered the principal payments on the loan, due in 30 years, and limited GP to the assets of one of the taxpayer's subsidiaries, with no provisions mandating that the subsidiary retain assets to cover the indemnity (Canal Corp., 135 T.C. at 10, 24-26). Based on this reasoning, the Tax Court denied the taxpayer claims and ruled that the transaction was, in fact, a disguised sale.

How does PRT relate to Canal Corp.? PRT offers an alternative approach to evaluating the disguised sale exception. From a PRT perspective the taxpayer's contribution to the partnership was unambiguously a sale of its paper business because the taxpayer transferred full control of its assets to the partner. That is, the taxpayer retained no authority over how those assets could be used. Similar to Castle Harbor, focusing on control provides a clearer standard than one that depends on determining whether a given party's financial risk is, subsequent to the transaction, substantial enough.

These two examples illustrate a general point: evaluating a sale based on control rights can be sufficient and allows the trier of fact to avoid the murkiness associated with establishing a specific cash-flow and risk threshold. Canal Corp. demonstrates the complexities of accounting for risk exposure in uncertain business environments over long periods of time and in the face of insurance contracts, indemnification clauses and inactive corporate subsidiaries. Common approaches to measuring risk are notoriously sensitive to the assumptions upon which they rely (See Brealey and Myers (2000, 259-268), discussing sensitivity analysis and Higgins (2009, 103-106)). A cynical view is that aiven transaction's terms may be structured to be complex so as to provide the appearance of substantial risk where none exists. Beyond that, since cash flows and risk profiles depend critically on control, evaluating the latter is a more direct route to determining ownership than is an evaluation of the former. 


\section{Conclusion}

The purpose of this paper has been to demonstrate how the economics of ownership and control, specifically PRT, can provide guidance in evaluating the appropriate tax treatments associated with complex corporate transactions. Evaluations of economic substance and/or business purpose in the context of a corporate transaction often depend on an assessment of whether a particular party's income claims look more like equity or more like debt, or on a present value calculation of the efficiency benefits flowing from the transaction. However, characterizing a party's income rights can be very challenging, and calculations of net present value are notoriously sensitive to assumptions and judgment.

The view advanced here is that there is an alternative approach that the courts can use that is simpler and, importantly, more directly captures the economic substance associated with ownership. According to PRT the fundamental property of ownership is control. Thus whether a corporate transaction has economic substance or a business purpose can be determined by evaluating whether the transaction involves a meaningful change in control. Did a key party who did not have control before the transaction gain control? Making such a determination can be relatively straightforward.

We have used the PRT approach to analyze the Black and Decker and Wells Fargo transactions. In both cases there was no meaningful change in control. Accordingly, PRT suggests that these transactions did not have economic substance or a business purpose. The district court in Wells Fargo agreed, and while it is the only known decision to rely on PRT to evaluate the merits of a tax-motivated transaction, we have seen that PRT is consistent with, and supports, the decisions in the Castle Harbor and Canal Corp. Cases. Of course, these four cases comprise a small subset of the universe of all cases. However, our belief and hope is that the approach described here has broad applicability and that it will be useful in future cases too.

Of course, a natural question to ask is: If the economic substance of a transaction is evaluated according to whether a shift in control rights occurs, might parties not simply respond by designing their transaction so that a shift in control does indeed occur? There is no doubt that this is a possible outcome in some cases. However, the costs of structuring a transaction in such a manner are likely to be significant. In the Black and Decker and Wells Fargo cases giving up control of employee and retiree health benefits on the one hand or real estate operations on the other is not something that either company ever seems to have contemplated. More generally, the research-both theoretical and empirical-cited in footnote 3 provides strong support for the idea that control is valuable and that giving it up can expose a company to serious risks. A company may, of course, arrange matters so that control appears to have been relinquished when it has not, but one would hope that the 
courts will be able to see through this. In summary we do not believe that gaming the system will be a serious obstacle to the evaluation of economic substance in terms of control. 


\section{Appendix: Contingent Liability Tax Shelters}

Section 351 of the Internal Revenue Code (26 U.S.C.) provides that no gain or loss shall be recognized if property is transferred to a corporation solely in exchange for stock so long as the transferor(s) control the corporation immediately after the exchange. The purpose of the provision is to save the transferor from the immediate recognition of gain (or loss) on the transfer of appreciated (or depreciated) business property for corporate stock. It recognizes that such an exchange is not a sale of the property, but a "mere change in the form of ownership and the taxpayer has not really 'cashed in' on a theoretical gain, or 'closed out' a losing venture". (Portland Oil Co. v. CIR, 109 F. 2d 479, 488 (1 $1^{\text {st }}$ Cir. , cert. denied 310 US 650 (1940). For that reason, an individual that transfers substantially all of the assets and liabilities of her sole proprietorship for all of the stock in a new corporation will not recognize any gain or loss until she sells the stock. Section 358 recognizes this mere change in form by providing that the taxpayer's basis in the stock she received will, with an important exception, be the same as her tax basis in the property she transferred minus, inter alia, the liabilities the corporation assumed.

However, suppose that a taxpayer transfers some assets and some contingent liabilities (liabilities whose amount or extent are not yet known) to the corporation. How should this transfer be treated for tax purposes? In 1995, the Internal Revenue Service issued Revenue Ruling 95-74 addressing the income tax consequences of a hypothetical transfer by a corporation of substantially all of its assets and associated contingent liabilities to a new corporation. Those assets consisted of a manufacturing plant and equipment, while the liabilities represented the remediation costs that the transferring company expected to incur in the future from environmental contamination caused by its operations. In return for its assets and the assumption of its contingent remediation liabilities, the transferring corporation received stock in the new corporation.

In the revenue ruling, the IRS assumed that the transfer of assets and contingent liabilities for stock qualified as a tax-free exchange under Section 351. The questions presented were 1) whether the tax basis in the stock acquired by the transferring corporation should be reduced by the amount of liabilities assumed by the new corporation; and 2) whether the new corporation could deduct the payments made on account of the contingent liabilities as they were actually incurred. The IRS determined that the transferee's tax basis in the stock of the new corporation (namely, the amount by which any gain or loss on its sale would be measured) was not reduced by the amount of the liabilities the new corporation assumed. Additionally, because the transferee had yet to incur those contingent liabilities, the IRS concluded that the payment of those liabilities could be deducted as business expenses by the new corporation. 
Consider the following practical example: Corporation A transfers property with a tax basis and value of $\$ 10$ million to Corporation B in exchange for Corporation B's assumption of $\$ 9$ million worth of contingent liabilities and 100 percent of the shares of Corporation B's stock. The market value of the stock is only $\$ 1$ million. However, the tax basis of the stock is $\$ 10$ million, because the contingent liabilities do not reduce the tax basis of the stock of the new corporation. If Corporation A were to sell the stock, it would realize a tax loss of $\$ 9$ million (the market value of the stock minus its tax basis). Furthermore, Corporation B can deduct the cost of its contingent liabilities as incurred. Since Corporation B is owned and controlled by Corporation A, Corporation A can receive what is effectively a double tax deduction, one stemming from the loss on the sale of the stock, and one stemming from deducting the costs associated with the contingent liabilities as incurred.

Revenue Ruling 95-74 clearly states that it is limited to the transfer of substantially all of the assets of a going concern for bona fide business purposes. That limitation, however, did not prevent promoters of aggressive tax strategies from exploiting the ruling to devise and market to corporate taxpayers with large taxable gains what came to be known as the "contingent liability tax shelter." The shelter they devised placed in the taxpayer's hands low-value high-basis stock in a controlled subsidiary that the taxpayer reorganized into a liability management company ("LMC"). Following the reorganization, the taxpayer transferred liquid assets and contingent liabilities (such as environmental cleanup costs, estimated medical costs of employees and retirees, anticipated payouts from productliability or other unliquidated claims) to the LMC for the new class of stock. Notably, the transfer had no effect on the taxpayer's core activities, nor did the taxpayer relinquish control over the reorganized subsidiary. Once the transfer was complete, the taxpayer sold the stock it received in the exchange to an accommodating party at a loss that the taxpayer used to offset taxable income. As one promoter outlined in a presentation entitled "Accelerating Contingent Liability Deductions," the transaction allows the participating taxpayer to accelerate the tax deduction it could otherwise take only when the contingent liabilities are actually incurred:

With proper planning and structuring of a series of transactions, a taxpayer may be able to significantly accelerate the deduction (in the form of a capital loss) of such contingent costs. Such planning involves the use of a risk management company or a health care management company and the sale of some of the stock of the company to a third party manager, consultant or investor. With this approach, the taxpayer may be able to deduct a capital loss equal to the amount of the contingency. In addition, the management company may later 
be entitled to a second deduction for the same amount over time as the expenditures are actually incurred.

In 1998, Congress added section 358(h) to the Internal Revenue Code to outlaw this scheme on a prospective basis. It provides that the basis of any stock acquired in a section 351 exchange that exceeds the stock's fair market value must be reduced by the amount of any liability assumed in the exchange. Applied to the above hypothetical, Corporation A's basis in Corporation B's stock would have been reduced by $\$ 9$ million, and the subsequent sale would have produced no gain or loss. Although Congress included exceptions that essentially codified Revenue Ruling 95-74 (by excluding transfers involving the trade or business that caused the liability, or substantially all of the assets with which the liability is associated), section 358(h) effectively put an end to the contingent liability tax shelter after the effective date of October 18, 1999.

To deal with the shelters that were implemented before that date, the IRS issued Notice 2001-17. The notice alerted taxpayers and promoters alike that the IRS intended to challenge the tax losses claimed from the sale of stock acquired from contingent liability tax shelter transactions on various grounds. Relevant to this paper is the IRS's contention that "the overall transaction lacks sufficient economic substance to be respected for tax purposes." 19

${ }^{19}$ The IRS also outlined a number of statutory arguments which are beyond the scope of this paper. For a detailed discussion of those issues, see Burke (2005, 219); U.S. Department of the Treasury (2001, 730). 


\section{REFERENCES}

Aghion, Philippe and Richard Holden. 2011. "Incomplete Contracts and the Theory of the Firm: What Have We Learned over the Past 25 Years?” Journal of Economic Perspectives, 25(2): 181-197.

Aghion, Philippe and Jean Tirole. 1997. "Formal and Real Authority in Organizations." Journal of Political Economy 105(1): 1-29.

Acemoglu,Daron, Philippe Aghion, Rachel Griffith, and Fabrizio Zilibotti. 2010. "Vertical Integration and Technology: Theory and Evidence.” Journal of European Economic Association 8:2-45.

Baker, George P., and Thomas Hubbard. 2003. "Make v. Buy in Trucking: Asset Ownership, Job Design and Inform ation." American Economic Review 93 (3): 551-572.

Baker, George P., and Thomas Hubbard. 2004. "Contractibility and Asset Ownership: OnBoard Computers and Governance in US Trucking." Quarterly Journal of Economics 119 (4): 1443-1480.

Bibicoff, Hillary. 1991. "Net Profit Participations in the Motion Picture Industry.” Loyola Entertainment Law Journal 11: 23-65.

Brealey, Richard A. and Stewart C. Myers. 2000. Principles of Corporate Finance, 6th Edition. New York: McGraw-Hill Higher Education.

Burke, Karen C. 2005. “Deconstructing Black \& Decker’s Contingent Liability Shelter: A Statutory Analysis.” Tax Notes 108(3): 211-221.

Caves, Richard E. 2003. “Contracts Between Art and Commerce.” Journal of Economic Perspectives 17 (2): 73-84.

Coase, Ronald H. 1937. "The Nature of the Firm.” Economica 4(16): 386-405.

Damodaran, Aswath. 2007. "What is Valuation?" http://pages.stern.nyu.edu/ adamodar/New_Home_Page/background/valintro.htm (last updated June 15, 2007).

Englebrecht, Ted D., Wei-Chih Chiang, and Y. Wang 2008. "An Empirical Assist for Management in Resolving the Debt Versus Equity Dilemma.” Journal of Business and Accounting, 1 (1): 121-137.

Financial Accounting Standards Board. 2010. "Project Updates: Financial Instruments with Characteristics of Equity (formerly Liabilities and Equity)—Joint Project of the FASB and IASB.” Last modified October 26, 2010, http://www.fasb.org/fi_with_characteristics_of_equity.shtml.

Glickman, Jeffrey C. and Clark R. Calhoun. 2008. “The ‘States’ of the Federal Common Law Tax Doctrines.” Tax Lawyer 61 (4):1181-.

Grossman, Sanford J., and Oliver Hart. 1986. "The Costs and Benefits of Ownership: A Theory of Vertical and Lateral Integration.” Journal of Political Economy 94(4): 691-719.

Grossman, Sanford J., and Oliver Hart. 1988. “One-share-one-vote and the Market for Corporate Control.” Journal of Financial Economics 20 (1/2): 175-202.

Harris, Milton and Arthur Raviv. 1988. “Corporate Governance: Voting Rights and Majority Rules.” Journal of Financial Economics 20 (1/2): 203-235.

Hart, Oliver. 1989. “An Economist’s Perspective on the Theory of the Firm.” Columbia Law Review 89 (7): 17571774.

Hart, Oliver. 1995. Firms, Contracts, and Financial Structure. Oxford: Oxford University Press

Hart, Oliver. 2008. "Reference Points and the Theory of the Firm.” Economica, 75(299): 404-11.

Hart, Oliver. 2009. “Hold-Up, Asset Ownership, and Reference Points.” Quarterly Journal of Economics, 124(1): 267-300.

Hart, Oliver, and Bengt R. Holmstrom. 2010. “A Theory of Firm Scope.” Quarterly Journal of Economics , 125(2): 483-512.

Hart, Oliver, and John Moore. 1990. "Property Rights and the Nature of the Firm.” Journal of Political Economy 98 (6): 1119-1158.

Hart, Oliver, and John Moore. 2008. "Contracts as Reference Points.” Quarterly Journal of Economics, 123(1): 148.

Higgins, Robert. 2009. Analysis for Financial Management, 9th Edition. New York: McGraw-Hill/Irwin.

Holmstrom,Bengt, and Jean Tirole. 1993. "Market Liquidity and Performance Monitoring." Journal of Political Economy 101:678-709.

Holmstrom, Bengt and John Roberts. 1998. “The Boundaries of the Firm Revisited.” Journal of Economic Perspectives, 12(4): 73-94.

Jensen, Michael C. 2001. "Value Maximization, Stakeholder theory, and the Corporate Objective Function." Journal of Applied Corporate Finance 14 (3): 8-21. 
Joskow, Paul. 1985. "Vertical Integration and Long-term Contracts: The Case of Coal-burning Electric Generating Plants.” Journal of Law, Economics, and Organization 1(1): 33-80.

Kaplan, Steven and Per Strömberg, 2003. "Financial contracting theory meets the real world: Evidence from venture capital contracts.” Review of Economic Studies 70(2): 281-316.

Kaye, Tracy A. 2010. “The Regulation of Corporate Tax Shelters in the United States.” American Journal of Comparative Law 58 (1):585-604.

Klein, B., Robert G. Crawford, and Armen A. Alchian. 1978. "Vertical Integration, Appropriable Rents, and the Competitive Contracting Process.” Journal of Law and Economics 21: 297-326.

Lafontaine, Francine, and Margaret Slade. 2007. “Vertical Integration and Firm Boundaries: The Evidence.” Journal of Economic Literature 45(3): 629-685.

Lederman, Leandra. 2010. “W(h)ither Economic Substance?” Iowa Law Review 95:389-444.

Shleifer, Andrei and Robert W. Vishny. 1997.” A Survey of Corporate Governance," Journal of Finance 52(2): 73783.

Silverman, Mark J. and Aaron P. Nocjar. 2011. “Partnership Disguised Sale Rules.” Practising Law Institute: Tax Strategies for Corporate Acquisitions, Dispositions, Spin-Offs, Joint Ventures, Financings, Reorganizations and Restructurings 2011, http://www.steptoe.com/assets/attachments/3734.pdf.

U.S. Department of the Treasury. Internal Revenue Service. 2001. “Contingent Liability Tax Shelter.” Internal Revenue Bulletin 2001-09, Notice 2001-17.

U.S. Department of the Treasury. Internal Revenue Service. 2010. "Interim Guidance Under the Codification of the Economic Substance Doctrine and Related Provisions in the Health Care and Education Reconciliation Act of 2010.” Internal Revenue Bulletin 2010-40, Notice 2010-62.

Whinston, Michael D. 2003. “On the Transaction Cost Determinants of Vertical Integration.” Journal of Law, Economics and Organization, 19 (1):1-23.

Williamson, Oliver E. 1975. Markets and Hierarchies: Analysis and Antitrust Implications. NewYork: Free Press.

Williamson, Oliver E. 1985. The Economic Institutions of Capitalism. New York: Free Press. 